\title{
Silurian retiolitids from the Cape Phillips Formation, Arctic Islands, Canada
}

\author{
A. C. LENZ AND M. J. MELCHIN
}

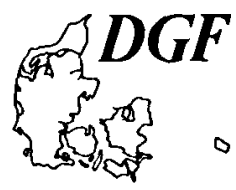

Lenz, A. C. \& Melchin, M. J. Silurian retiolitids from the Cape Phillips Formation, Arctic Islands, Canada. Bull. geol. Soc. Denmark, vol. 35, pp. 161-170, Copenhagen, July 1st, 1987. https://doi.org/10.37570/bgsd-1986-35-17

\begin{abstract}
Isolated retiolitids recovered from limestone concretions in the Cape Phillips Formation include Pseudo-plegmatograptus obesus obesus, Pseudoretiolites cf. decurtatus, Retiolites geinitzianus densireticulatus, Sto-matograptus grandis grandis, S. grandis imperfectus, S. sp., Paraplectograptus eiseli, P. praemacilentus, $P$. sp. A, Plectograptus (Sokolovograptus) textor, Gothograptus eisenacki and Holoretiolites simplex.

Plectograptus? textor is assigned to Plectograptus (Sokolovograptus), the definition of Paraplectograptus is expanded to include morphs with a weak reticulum, and we show that reticular development and density is highly variable within these genera.

Retiolites may occasionally retain a partially to well developed prosicula; Stomatograptus and Pseudoplegmatograptus have a consistently well developed prosicula; and Pseudoretiolites possesses a well developed prosicula and, rarely, a metasicula. A sicula has not been seen in either Plectograptus (Sokolovograptus) or Paraplectograptus.

Surface sculpture is consistent within the subfamilies Retiolitinae and Plectograptinae, and serves to dis-tinguish them.

Age ranges of taxa recovered in this study are as follows. Pseudoretiolites: triangulatus/magnus to turriculatus zones; Pseudoplegmatograptus: turriculatus Zone; Stomatograptus spp.: spiralis to testis zones; Retiolites densireticulatus: spiralis to testis zones; Plectograptus (Sokolovograptus) textor: turriculatus to nassa zones; Paraplectograptus spp.: turriculatus to nassa zones; Gothograptus eisenacki: nassa Zone; Holoretio-lites: nilssoni Zone.
\end{abstract}

A. C. Lenz \& M. J. Melchin, Department of Geology, University of Western Ontario, London, Canada N6A SB7. August 29th, 1986

\section{Introduction}

Retiolitids are, by virtue of their beautifully symmetrical and delicate meshwork structure, inherently fascinating organisms. However, because of these same features, as well as the small size of some, the structures, growth and development of these taxa are inadequately known.

The recovery of free, uncompressed specimens of retiolitids from limestone concretions in the Cape Phillips Formation of the Canadian Arctic Islands presented a unique opportunity. The specimens of most taxa are abundant, preservation is exquisite, and growth stages of most are present. Moreover, graptolite-bearing concretions occur in shales in more or less continuously exposed sequences ranging in age from mid Llandovery to early Ludlow.

In spite of the fact that Silurian retiolitids have long been known and illustrated, the numbers of isolated specimens are, with the exception of such classic studies as Tullberg (1883), Holm (1890), Wiman (1896), and especially Eisenack
(1931, 1935, 1951, 1966), relatively few. The present study, in addition to recovering a number poorly known taxa, fills in some of the stratigraphic gaps left in earlier studies.

\section{Material}

The graptolite-bearing facies of the central and northern Artic Islands have been named the Cape Phillips Formation by Thorsteinsson (1958). Graptolites are generally abundant both in compressed form in the shales, and uncompressed form in the enclosed limestone concretions (Thorsteinsson, 1958; Thorsteinsson and Kerr, 1968; Lenz, 1978). The Cape Phillips ranges in age from Late Ordovician (Ashgill) to Early Devonian, but graptolite-bearing nodules are most common in Llandovery to lower Ludlow strata.

Uncompressed graptolites, including the retiolitids of this study, were recovered from eight areas (fig. 1). The material studied was collected 


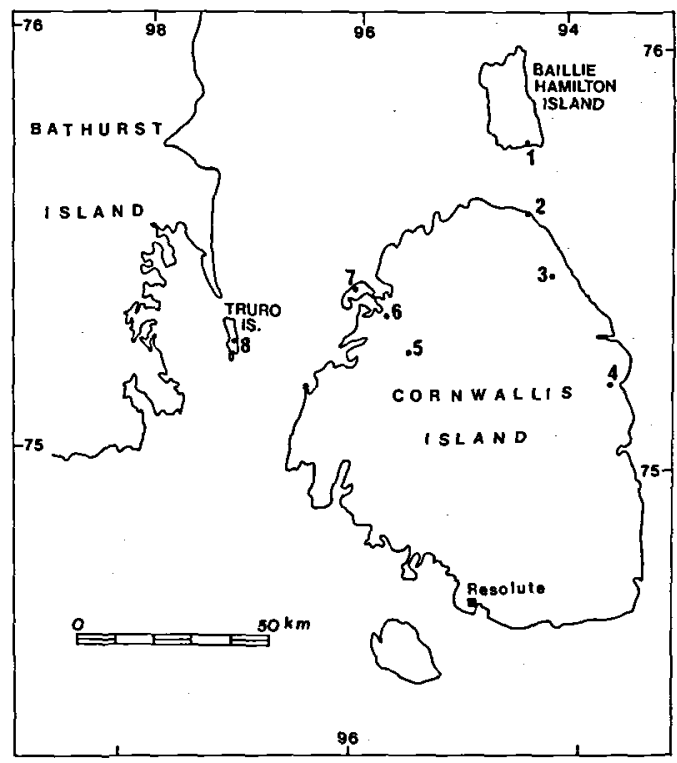

Fig. 1. Index map showing sample localities. Localities are as follows: 1. southern Baillie Hamilton Island $\left(75^{\circ} 45^{\prime} \mathrm{N}\right.$, $\left.94^{\circ} 22^{\prime} \mathrm{W}\right) ; 2$. Cape Phillips (the type section) $\left(75^{\circ} 37^{\prime} \mathrm{N}\right.$, $\left.94^{\circ} 22^{\prime} \mathrm{W}\right) ; 3$. southwest of Cape Manning $\left(75^{\circ} 27^{\prime} \mathrm{N}, 94^{\circ} 18^{\prime} \mathrm{W}\right)$; 4. Laura Lakes area $\left(75^{\circ} 11^{\prime} \mathrm{N}, 93^{\circ} 19^{\prime} \mathrm{W}\right) ; 5$. Abbott River $\left(75^{\circ} 14^{\prime} \mathrm{N}, 95^{\circ} 36^{\prime} \mathrm{W}\right)$; 6. Rookery Creek $\left(75^{\circ} 22^{\prime} \mathrm{N}, 95^{\circ} 42^{\prime} \mathrm{W}\right) ; 7$. Marshall Peninsual $\left(75^{\circ} 26^{\prime} \mathrm{N}, 96^{\circ} 05^{\prime} \mathrm{W}\right) ; 8$. Truro Island $\left(75^{\circ} 17^{\prime} \mathrm{N}, 97^{\circ} 08^{\prime} \mathrm{W}\right)$.

from strata of the mid Llandovery triangulatus or magnus zones to the latest Wenlock lundgrenil testis Zone or the apparently slightly younger nassa Zone. Only rare specimens of Holoretiolites were recovered from lower Ludlow strata. Age determinations of the retiolitids were by means of the associated monograptid faunas.

\section{Systematic Paleontology}

In this section, we focus discussion on the overall morphologic characteristics of the genera, and species are only briefly discussed. Furthermore, very little discussion is devoted to periderm fine structure since that aspect has already been admirably covered in the works of Andres (1977), Crowther and Rickards (1977), Bates and Kirk (1978) and Crowther (1981).

\section{Family RETIOLITIDAE Lapworth 1873}

Subfamily RETIOLITINAE Lapworth 1873, emended herein

Well developed reticula supported on a distinct clathria; sicula unsclerotized or partially sclerotized (prosicula and, rarely, metasicula); ancora stage stage well developed. Clathrial 'seams' face in, reticular 'seams' face out; surface fine structure of longitudinal striations composed of peridermal fibrils.

\section{Remarks}

The surface sculpture is consistent in all members in each of the two subfamilies. The variable occurrence of a prosicula and, rarely, metasicula, cannot be used as a diagnostic criterion of the subfamily (cf. BuIman, 1970, p. 108).

\section{Genus PSEUDOPLEGMATOGRAPTUS Pŕíbyl 1948}

Diagnosis

Prosicula well developed. Virgella distally forming 4-pronged ancora which develops into basket-shaped corona formed of 2-3 crude rows of cells. Lateral bar from near apex of sicula splits into 2 parietal lists to form theca $1^{1}$. Virgula moves quickly to ventral side of rhabdosome, alternately giving off short branches to 'left' and 'right'. Branch divides into short ventral and long dorsal, branch to form aboral list; these in turn divide and project laterally to form parietal lists. Zig-zag line on dorsal side alternately joins 'left' and 'right' thecal lists. Thecae orthograptid in profile, bases marked by a single median thread joining centre of thecal lip and aboral list of previous theca. Thecal spines developed near margin of thecal lips, projecting proximally and laterally (pl. 1, fig. 1). Lacinia not seen. Reticulum of very irregular meshwork; meshes vary considerably in size and shape. Large irregular openings (stomata) present along medial line. Rhabdosome ovate in cross-section. Fine structure of lists comprises longitudinal striations only.

\begin{abstract}
Remarks
Characteristics of the genus are the irregularly-sized and shaped meshes of the reticula and the paired, proximo-laterally directed thecal spines (see for example Törnquist (1890), Elles and Wood (1908), Bouček and Münch (1944), Münch (1952), Schauer (1971), Hutt (1974), Lenz (1978). The genus is well known but the complex nature of the clathrium and reticulum has not been previously understood. This study, however, has shown that the clathrium, while more complex than that of for example Retiolites, is in most ways remarkably similar. The presence of stomata is previously unreported in the genus. The stomata are irregular in outline, show no indication of thick-
\end{abstract}

Plate 1

Fig. 1. Pseudoplegmatograptus obesus obesus Lapworth. Stereopair. Field number LL $1, \times 10$. GSC 78423

Figs. 2, 8. Pseudoretiolites cf. decurtatus Bouček \& Münch. Proximal end and sicula. Field number MRC $02, \times 50$. GSC 78424

Fig. 3. Pseudoretiolites cf. decurtatus; metasicula. Field number LL $1, \times 210$. GSC 78425

Fig. 4. Pseudoretiolites cf. decurtatus. Field number ML 64 upper, $\times 13$. GSC 78426

Fig. 5. Pseudoretiolites cf. decurtatus. Stereopair of proximal end. Field number ML 64 upper, $\times 32$. GSC 78426

Fig. 6. Pseudoretiolites cf. decurtatus. Stereopair of distal end of laterally flattened specimen. Field number MRC 02, $\times 10$. GSC 78428

Fig. 7. Pseudoretiolites cf. decurtatus. Prosicula. Field number ML 64 upper, $\times 150$. GSC 78426

Fig. 9. Plectograptus (Sokolovograptus) textor Bouček \& Münch. Field number CP $390-400, \times 18$. GSC 78430 

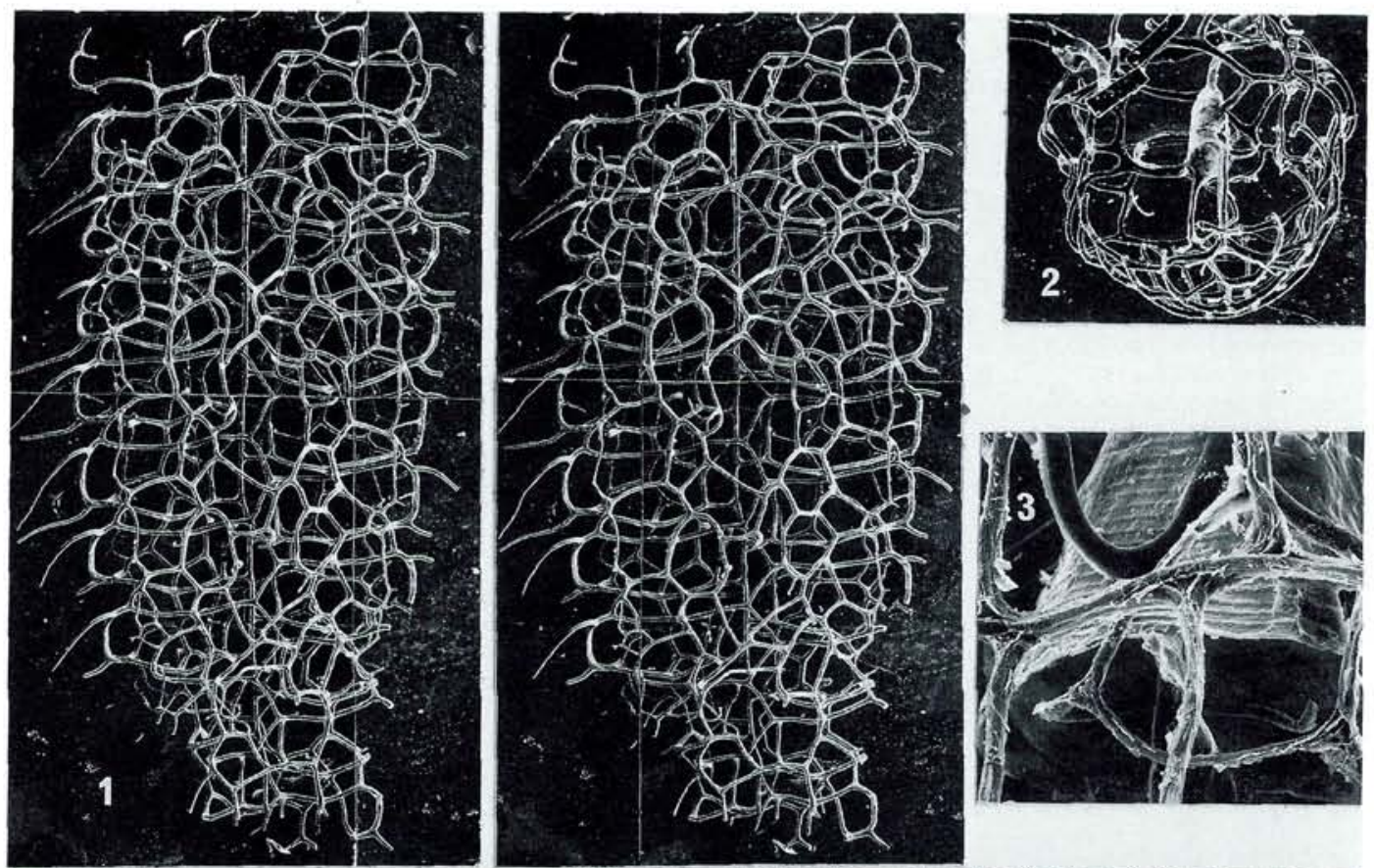
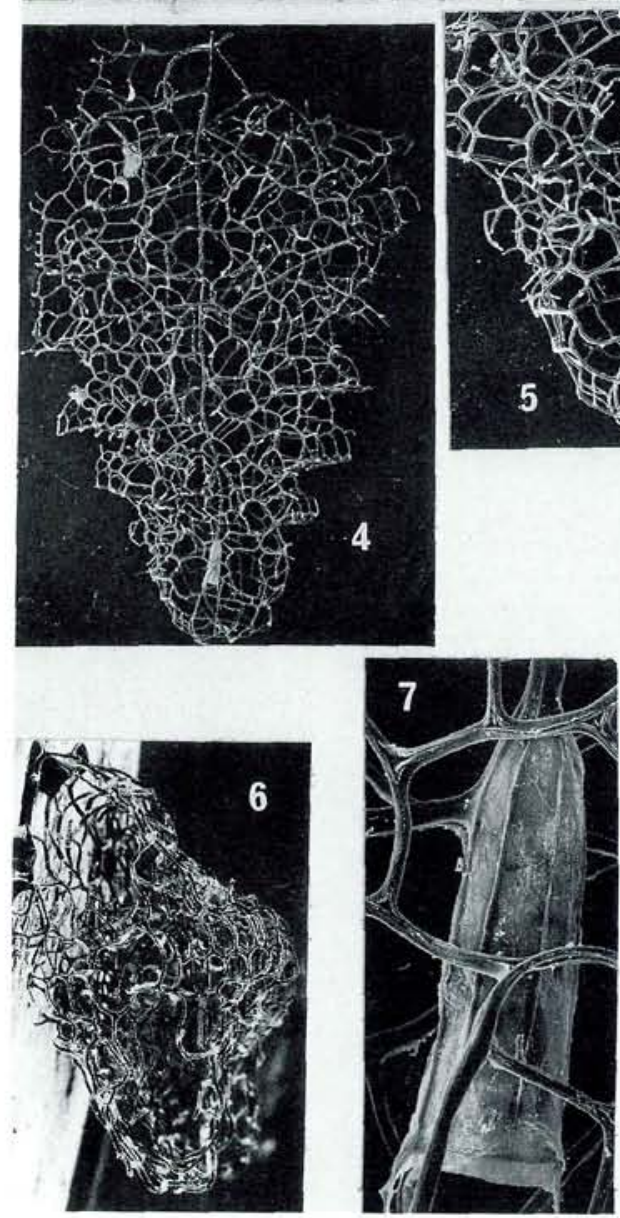
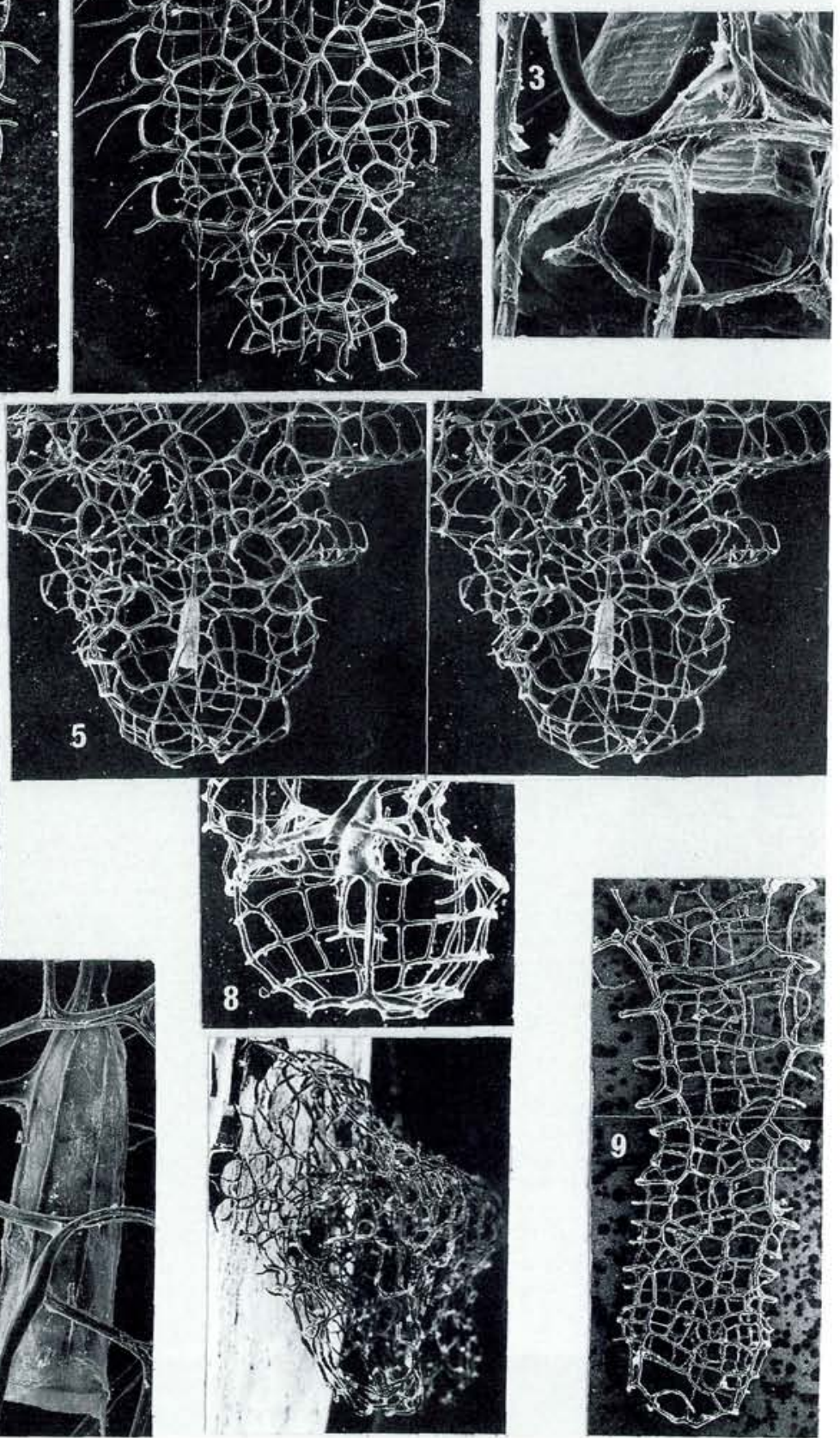
ened rims and, like those of Stomatograptus, are elevated above the area of the surrounding reticula.

The lack of any evidence of a lacinia requires comment. By analogy with the sclerotized ventral walls of the thecae of Stomatograptus, the lacinia must have been very delicate. Furthermore, most compressed specimens are without lacinia. In fact some illustrations such as those of Figs: $223 \mathrm{a}, \mathrm{b}, \mathrm{c}$ of Elles and Wood (1908) and especially Text-fig. 12 of Hutt (1974) can, by comparison with the uncompressed material of this study, clearly be seen to be laterally flattened and distorted elements of the thecal lips and spines.

All specimens except one, recovered in this study are assignable to P. obesus obesus Lapworth. Parameters are as follows: maximum width of somewhat flattened fragments: $4.5 \mathrm{~mm}$; thecae about 12 in $10 \mathrm{~mm}$; mesh of reticula difficult to measure, 3-5 in $2 \mathrm{~mm}$; spines at least $1.2 \mathrm{~mm}$ long. The one exception is presumably assignable to $P$. longispinus Bouček and Münch because of its overall finer mesh (about 6 in $2 \mathrm{~mm}$ ), 1-2 rows of finer ovate meshes along the lateral margins of the thecae, and spines at least $2.5 \mathrm{~mm}$ long.

Occurrence and Age

Found only at Laura Lakes area in the Late Llandovery turriculatus Zone.

\section{Genus PSEUDORETIOLITES Bouček and Münch 1944 Diagnosis}

Prosicula characteristically present (pl. 1, fig. 7); metasicula rarely preserved (pl. 1, fig. 3). Corona developed from fourpronged ancora, hemispherical and basket-like, formed of 3-4 rows of gently spiralled lists joined to longitudinally arrayed lists (pl. 1, fig. 5). In specimens with metasicula, "struts" anchor sicula to reticula. First theca develops from clathrial list arising from mouth of sicula; second theca formed from clathrial bar emerging near top of sicula; remaining thecae developing in manner similar to that of Pseudoplegmatograptus. 'Floor' of theca marked by long median list arising from aboral list of previous theca and connected to lip of theca. Lip of theca formed of fine, laterally elongate meshes, divided medially by a zig-zag list. Thecae distinctly orthograptid in profile, with moderately accentuated lips and curved, anterolaterally directed apertures. Reticulum moderately fine, meshwork polygonal, with meshes of more or leass uniform size. Median region of both sides of rhabdosome generally bear large, irregularly shaped, thinwalled stomata, the margins of which stand above the adjacent reticula. Stomata at least twice the size of reticulum mesh-size.

\section{Remarks}

Obut and Zaslavskaya (1976) tentatively suggested that Pseudoretiolites be assigned to a separate (new) subfamily Pseudoretiolitinae because of the presence of a metasicula. However, in view of the fact that the metasicula is rarely present (at least in our material), and that clathrial development is essentially like that of Retiolites, the move seems unnecessary.

The corona with its beautiful symmetry and nearly square meshes, the moderately regular reticular meshwork, the normally poorly-seen clathrium, and the dense mesh network forming the lip of theca, are all distinctive of the genus and are, we feel, sufficient justification for the retention of Pseudoretiolites as a separate taxon, unlike Bulman (1970) who placed it in synonymy with Retiolites. The basket- like corona is especially diagnostic, and make recognition of the genus easy.

Some studies, based on the study of flattened specimens, note the presence of 'membranes' (eg. Perner (1899), Elles and Wood (1908), Bouček and Münch (1944), Münch (1952), Hutt (1974)). On the other hand, the excellent but flattened material of Chen (1983) gives no indication of 'membranes', while clearly showing the fine meshwork forming the lip of the thecae as is recognized in all our specimens. We have seen no sclerotization or membrane formation and offer no overall explanation, but we do suggest that the flattening of the fine meshwork of the thecae could readily lead to the appearance of a continuous membrane in these areas.

One species, $P$. cf. decurtatus Bouček and Münch, has been recovered. It is characteristiized by a ovate rhabdosome outline, the cae 14-12 in $10 \mathrm{~mm}$, reticular meshwork 6-7 in $2 \mathrm{~mm}$, maximum length of incomplete specimen $8.5 \mathrm{~mm}$, and ovate stomata about $1.2 \mathrm{~mm}$ long.

\section{Occurrence and Age}

Found at Rookery Creek and southwest of Cape Manning in the triangulatus/magnus, convolutus and turriculatus zones; fairly common.

\section{Genus RETIOLITES Barrande 1850 (not illustrated) \\ Remarks}

Retiolites, particularly of the geinitzianus group, is widely known, and its morphology has been understood for nearly 100 years (see for example, Holm (1890), Bulman (especially illustration of 1938, fig. 40c), Boucek and Münch (1944), and particularly the SEM studies of Bates and Kirk (1978) and Crowther (1981)).

Characteristics of the $R$, geinitzianus group include the relatively low, parabola-shaped corona made up of relatively few and coarse, polygonal meshes and the accompanying two large pores at the 'top' of the corona; the very robust clathria with strong parietal lists welded to the reticula and clearly marking the position of the thecae; the thecal apertures which distally are more or less parallel to the rhabdosome; and the strong, fine, relatively uniform sized meshwork of the reticula. The development of 'thecal hoods' over the 3-4 proximal thecae is not widely known, athough they and the succeeding 'thecal con-

Plate 2

Fig. 1. Stomatograptus grandis imperfectus Bouček. Field number MCP 165, $\times 8$. GSC 78431

Fig. 2. Stomatograptus grandis grandis (Suess). Field number MCP 165, $\times 8$. GSC 78432

Figs 3, 12. Holoretiolites simplex (Eisenack). Distal and proximal portions. Field number LL 10, $\times 35$. GSC 78433

Fig. 4. Stomatograptus grandis imperfectus. Enlargement of theca of fig. 1, showing remnants of thecal "floors". Field number MCP 165, $\times 50$. GSC 78431

Fig. 5. Gothograptus eisenacki Obut \& Sobolevskaya. Field number LL 7, ×20. GSC 78434

Fig. 6. Stomatograptus sp. Field number CP 400-450, $\times 10$. GSC 78435

Fig. 7, 8. Stomatograptus sp. Immature rhabdosome and enlargement of the prosicula. Field number LL B-81, $\times 30$ \& $\times 225$. GSC 78436

Fig. 9. Distal end showing virgula, crosssection of the thecae and projecting mouth of stomata. Field number CP $450-500, \times 18$. GSC 78427

Figs. 10, 11. Stomatograptus $\mathrm{sp}$. Rhabdosome and lateral view showing thecae. Field number MCP $165, \times 10 \& \times 13$. GSC 78437

Fig. 13. Gothograptus eisenacki Obut \& Sobolevskaya. Field number MRC 05 top, $\times 30$ GSC 78438

Fig. 14. Gothograptus eisenacki. Field number MRC 05 top, $\times 25$. GSC 78439 

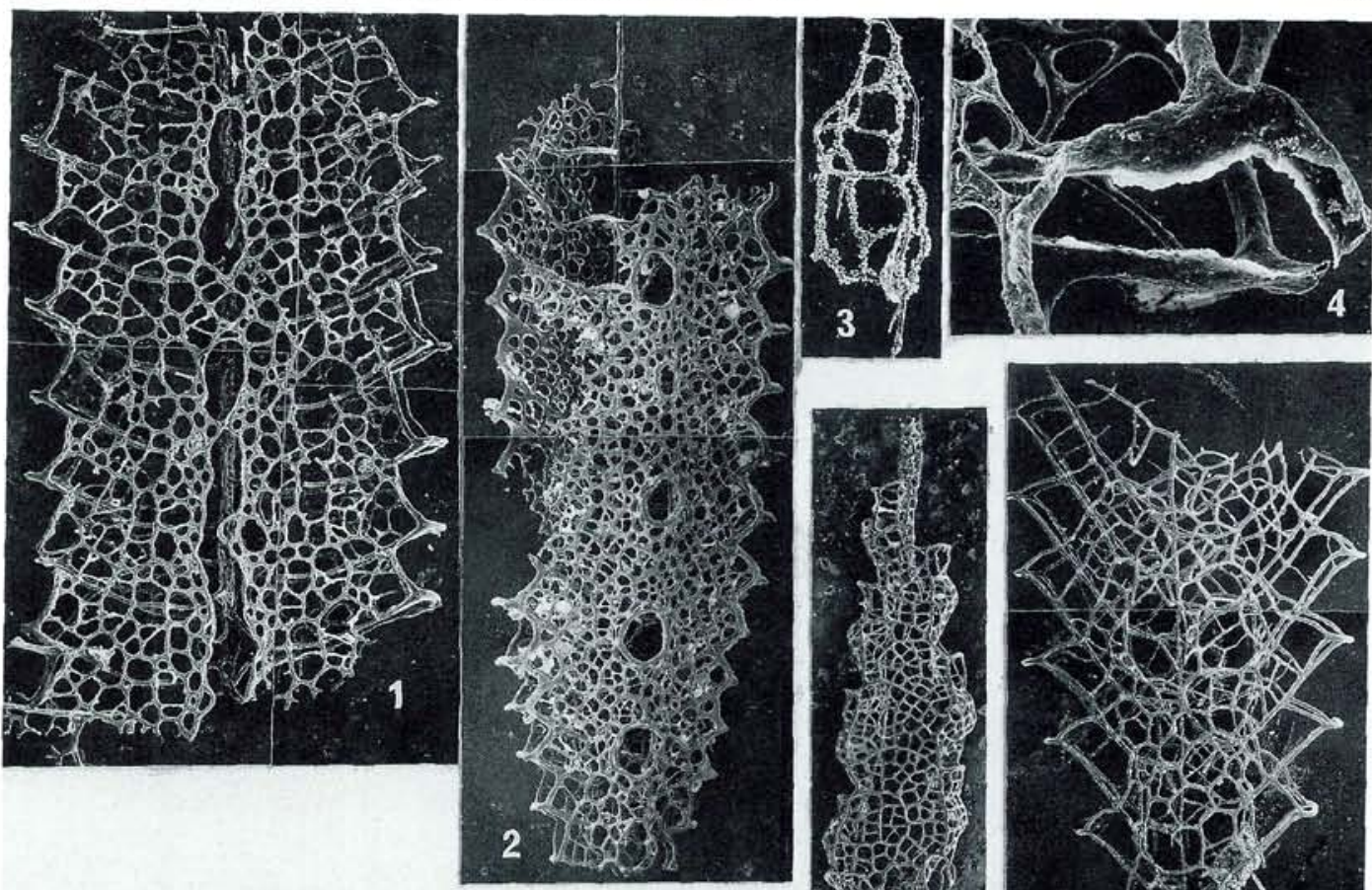

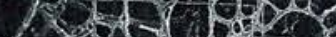

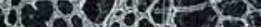
$100.6 \mathrm{H}$.

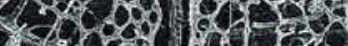
L 20 s.

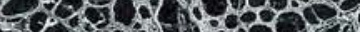

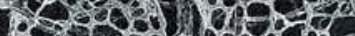
2 20.5.

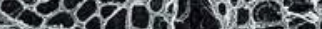
7 -

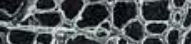
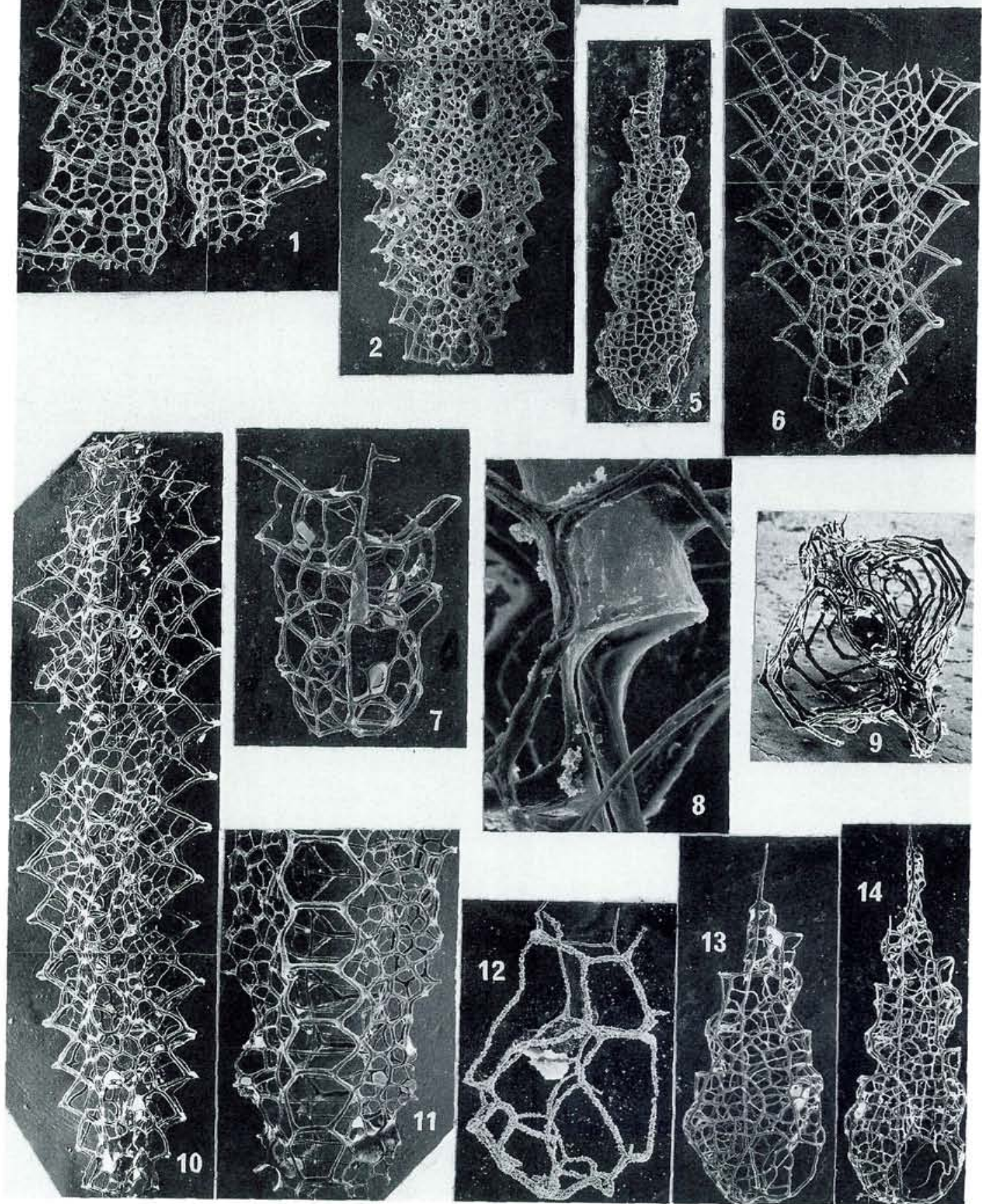
strictions' were illustrated by Crowther (1981). Specimens which otherwise are identical may or may not possess hoods and constrictions, although they are more common in, but not restricted to, stratigraphically lower specimens.

The presence of a prosicula in the geinitzianus group has been documented by Kühne (1953) and Obut and Zaslavskaya (1976). However, the present study shows that in the great majority of cases, no evidence of the prosicula remains, and that the nature of the prosicula is variable: some siculae are represented by a thickening, some by $2-3$ threads, some by only the anterior portion and, most rarely, by a complete prosicula.

One species, $R$. geinitzianus densireticulatus Bouček, is recognized in this study. It is characterized by a maximum uncompressed width of $3.5 \mathrm{~mm}, 14-11$ thecae in $10 \mathrm{~mm}$, thecae about 2 times longer than wide and inclined about $50^{\circ}$ to the virgula and, above all, a fine reticulum. The meshes form 4-5 rows per theca and are spaced about 6 per $\mathrm{mm}$. It differs from $R$. $g$. angustidens in possessing a much finer reticulum.

\section{Occurrence and Age}

Occurs commonly in every section; appears in the late Llandovery spiralis Zone and extends to the late Wenlock lundgreniltestis Zone. It is most abundant in the spiralis and grandis (= sakmaricus) zones.

\section{Genus STOMATOGRAPTUS Tullberg 1883}

Remarks

The overall similarity between the morphology of Retiolites and Stomatograptus has long been recognized, and in fact Bouček and Münch (1944) in their diagnosis of the latter genus simply state (p. 46) "... sonst wie die Untergattung Retiolites". The presence of large and distinct median stomata, generally with thickened rims, and of solid thecal walls, was beautifully shown by Holm (1890) and these features are generally considered to be characteristic of Stomatograptus (see Bulman, 1970, p. V130).

Stomata of various sizes are present in all Cape Phillips specimens, but it is interesting to note that in one fully developed, large specimen, stomata are irregular and even joined (pl. 2, fig. 1), a feature which surely must have weakened the rhabdosome and throws doubt on Rickards, et al. (1977, p. 31) statement that stomata "... are almost certainly a strengthening feature of the reticula". Furthermore, the walls of the stomata of some specimens are not in the least thickened.

The other diagnostic feature, that of the solid thecal walls, has not been observed in any of the Cape Phillips specimens. However, a close examination of the lists where the 'floor' of the theca would have been clearly shows thin and ragged remnants of the wall (pl. 2, fig. 4). It is probable therefore, that acid treatment destroyed the delicate walls. The supposed porebearing Retiolites described by Bjerreskov (1975) might then be explainable as a Stomatograptus which has had its thecal walls destroyed.

The proximal end of the genus consistently shows the presence of a well developed prosicula, while the corona is crudely rounded, basketshaped and composed of relatively small and regular polygonal meshes.

Several taxa are recognized, or tentatively recognized, in this study; ie, $S$. grandis grandis (Suess) (pl. 2, fig. 2), S. grandis imperfectus Boucek and Münch (pl. 2, figs. 1,4) and $S$. sp. (pl. 2 , figs. $6,8,10$ ). The first named taxon is characterized by having a maximum uncompressed width of $4 \mathrm{~mm}$, thecal spacing of about 6.5 in $5 \mathrm{~mm}$, thecae inclined at $50^{\circ}-60^{\circ}$ to the virgula, subrounded, heavy-rimmed stomata $0.6-0.7 \mathrm{~mm}$ in diameter and a dense reticula with uniform, fine mesh sizes. $S$. g. imperfectus is incomplete, but $5 \mathrm{~mm}$ wide with thecae numbering 5 in $5 \mathrm{~mm}$ distally and inclined about $50^{\circ}-60^{\circ}$ to the virgula, thecal lips are acute and moderately projecting, and the reticular meshwork is coarser than that of $S$. grandis grandis. $S$. sp. possesses a slowly widening rhabdosome, thecae which are distinctly orthograptid in profile, numbering 5-6 in $5 \mathrm{~mm}$, and inclined at $30^{\circ}-50^{\circ}$ to the virgula; the reticular meshwork is moderately fine proximally but becomes increasingly coarse and quadrate distally.

Most juvenile specimens from the highest range of the genus must, of necessity, also be assigned to ' $S$. sp.'.

\section{Occurrence and Age}

Large specimens are common in the spiralis and sakmaricus zones of most sections, and rarer juveniles occur in the late Wenlock lundgreniltestis Zone. $S$. grandis grandis is found only in the spiralis Zone:

Subfamily PLECTOGRAPTINAE Bourek and Münch, 1952; emended herein

Clathria well developed, sometimes without reticula, lacinia absent; development with ancora stage; proximal end of rhabdosome usually somewhat inflated (corona), narrowing distally and in some genera terminates in a slender tubular "appendix". Virgula free or incorporated into ventral wall. Surface of lists pustulose on outside surface (pl. 3, fig. 6). Seams of the clathria and reticula generally face in and out, respectively.

\section{Genus PLECTOGRAPTUS Moberg and Törnquist, 1909} Remarks

The genus is typically characterized by a clathria of open, subhexagonal meshes and a free, central virgula. $P$. macilentus, the type species, while not recovered uncompressed, occurs in

Plate 3

Fig. 1. Gothograptus eisenacki Obut \& Sobolevskaya. Field number MRC 05, ×23, GSC 78440

Fig. 2. Paraplectograptus praemacilentus Boucek \& Münch. Stereopair of simple rhabdosome. Field number CP $600-625, \times 15$. GSC 78441

Fig. 3. Paraplectograptus praemacilentus. Stereopair. Field number CP $450-500, \times 20$. GSC 78442

Fig. 4. Paraplectograptus eiseli (Manck). Field number RK 20-26C, $\times 15$. GSC 78443

Fig. 5. Paraplectograptus praemacilentus. Same as fig. 2, distal end of thabdosome showing virgula. Field number $\mathrm{CP} 600-625, \times 30$. GSC 78441

Fig. 6. Plectograptus (Sokolovograptus) textor Bouček \& Münch Field number CP 390-400, ×150. GSC 78444

Fig. 7. Paraplectograptus sp. A. Field number CP 450-500, $\times 20$. GSC 78445

Fig. 8. Gothograptus eisenacki. Field number MRC 05 top, $\times 28$. GSC 78446

Fig. 9. Paraplectograptus praemacilentus ( $=$ "Retiolites tenuis" Eisenack?). Field number LL $9, \times 40$. Specimen destroyed.

Fig. 10. Plectograptus (Sokolovograptus) textor. Field number CP 390-400, $\times 15$. GSC 78449

Fig. 11. Paraplectograptus eiseli? Field number CP 315-325, $\times 13$. GSC 78449

Fig. 12. Paraplectograptus eiseli. Stereopair. Field number MCP 152.5, $\times 20$. GSC 78450

Fig. 13. Plectograptus (Sokolovograptus) textor. Field number CP 390-400, $\times 17$. GSC 78451 

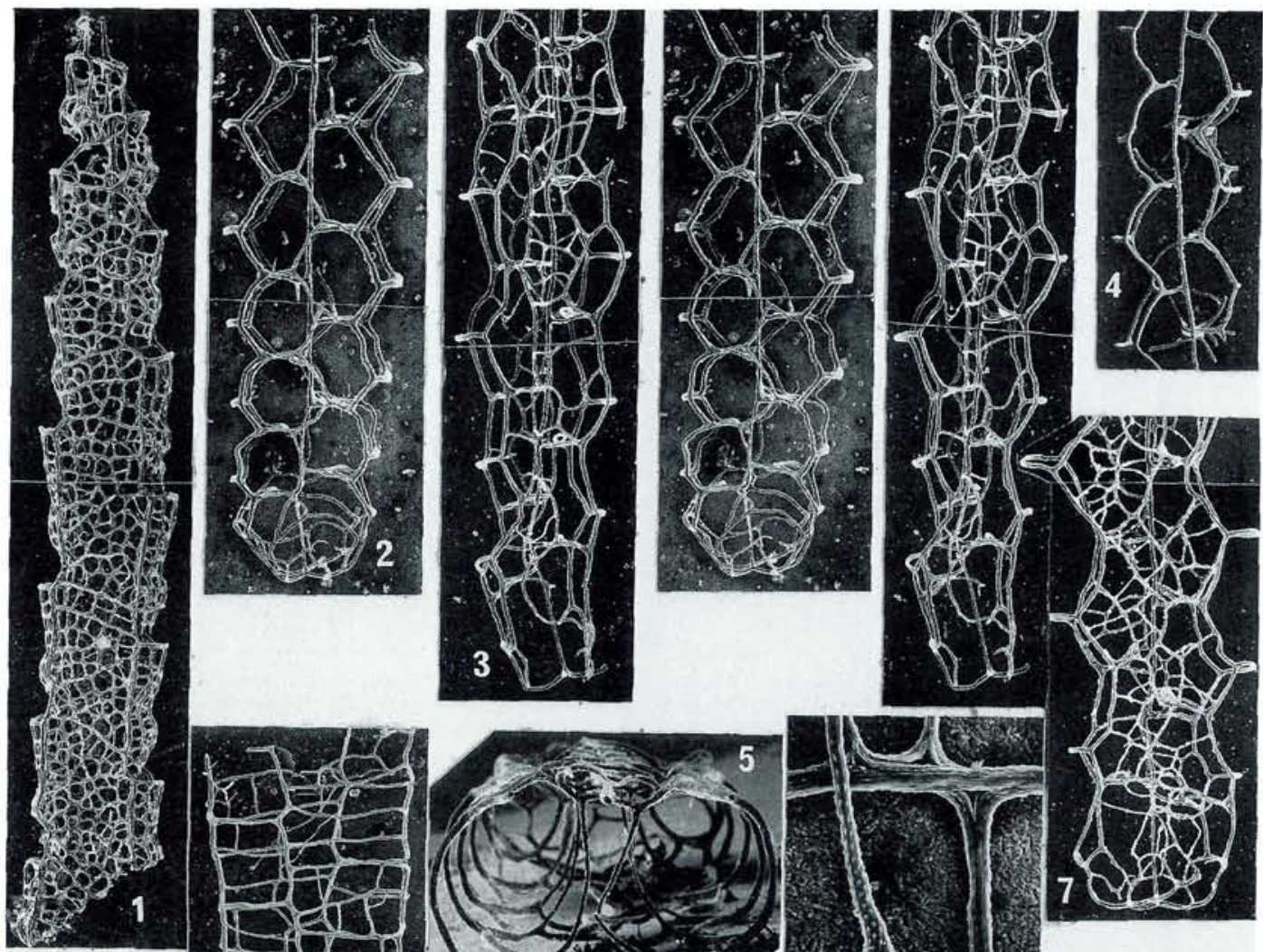

was

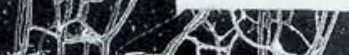

IN $\approx$ है \&5)
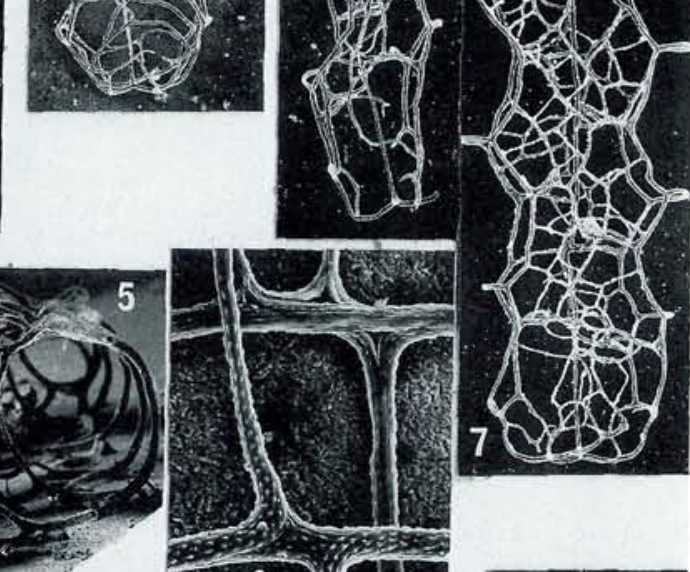
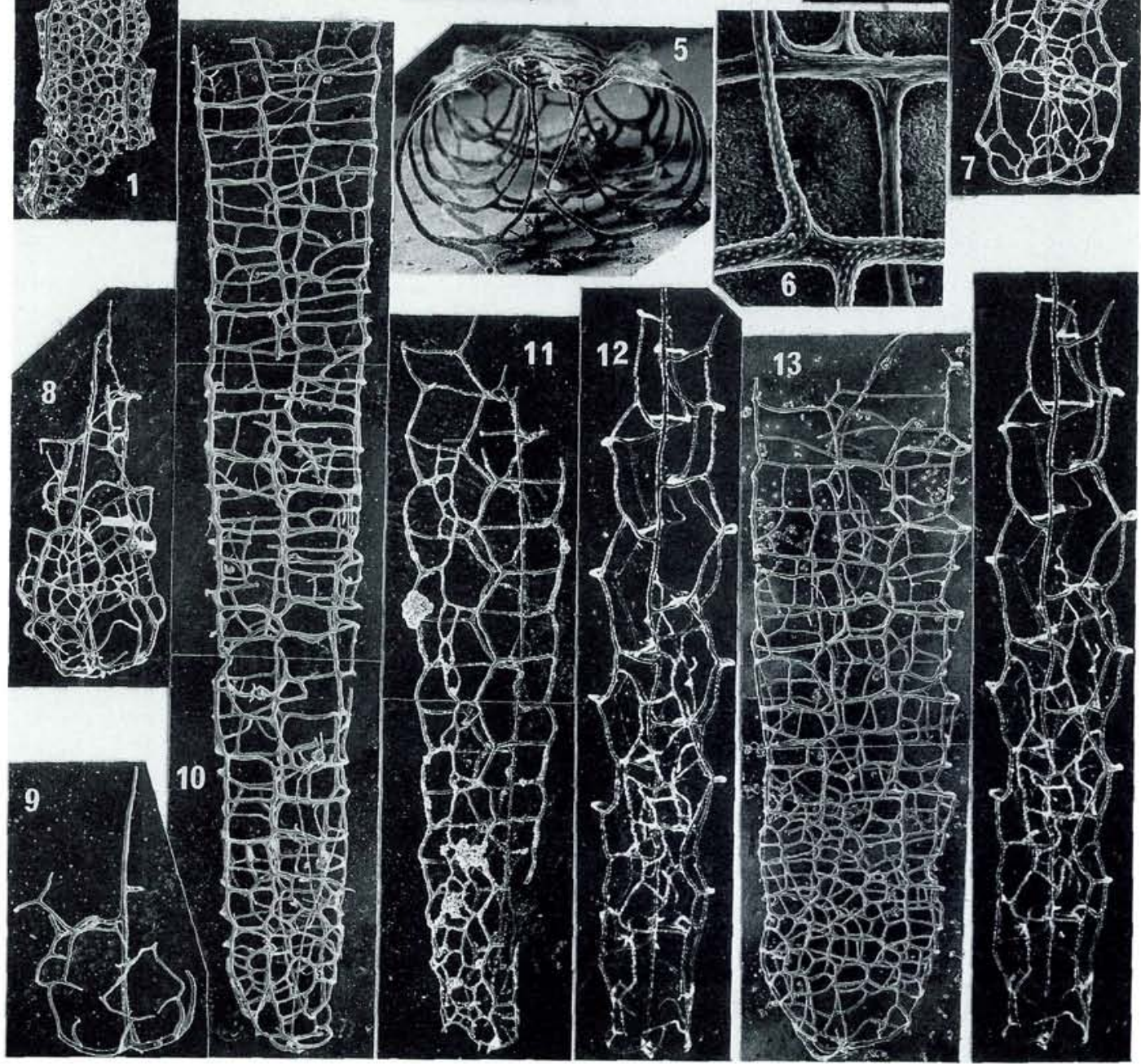
compressed form in Lower Ludlow strata of the Cape Phillips Formation (Jackson, et al., 1978).

Subgenus SOKOLOVOGRAPTUS Obut and Zaslavskaya, 1976 (= Genus Sokolovograptus Obut and Sobolevskaya, 1976) Type species: Plectograptus? textor Boucek and Münch, 1952. Species assigned: Plectograptus? textor Boucek and Münch, 1952.

Sokolovograptus parens Obut and Zaslavskayá, 1976.

Plectograptus? bouceki Rickards, 1967.

\section{Diagnosis}

Virgula free, attached only to ancora, extends only to level of theca 4 or 5 . Corona of few lists, weakly rounded, rectangular in cross-section. Clathrium and reticulum complex and disorderly, meshes polygonal to triangular to quadrate, relatively fine proximally, becoming coarser distally. Thecae generally climacograptid proximally (pl. 3, fig. 13), more or less orthograptid distally. Thecae marked by one or two shorter, transverse, curved lists, the outer margins of which are sometimes joined by a vertical list, and by a longer and more projecting lower apertural lip. Rhabdosome rectangular in crosssection, widening abruptly proximally, and then maintaining constant width or widening very gradually. Occasional specimens narrow slightly distally. Seams of lists all face inward making distinction between clathrium and reticulum difficult; in this way it differs from other plectograptids.

\section{Remarks}

This subgenus is similar to the type Plectograptus macilentus in its possession of a free central virgula and rectangular cross-section; it differs markedly, however, in the possession of a complex and disorderly clathrium/reticulum. Bouček and Münch (1952) tentatively suggested that $P$. textor might be assignable to a new subgenus of Plectograptus.

Obut and Zaslavskaya (1976) noted the occurrence of a delicate prosicula in juvenile stages of $S$. parens; we have not recovered any prosicula-bearing specimens of $P$. (Sokolovograptus) textor.

We recognize one species, $P$. (Sokolovograptus) textor, from the Cape Phillips. It is characterized by an extremely variable meshwork, a width of 0.7-1.5 mm exclusive of apertural lips and $0.9-2.0 \mathrm{~mm}$ inclusive of apertural lips, a thecal spacing of $7-8$ in $5 \mathrm{~mm}$, and a length of at least $8 \mathrm{~mm}$. P. (S.) textor differs from the species described as $P$.? bouceki by Rickards (1967), in being narrower, possessing more closely spaced thecae, and apparently possessing a coarser clathrial meshwork and somewhat different thecal apertural lists. It differs from $S$. parens Obut and Zaslavskaya primarily in being much wider, but is otherwise very similar and might possibly be conspecific.

\section{Occurrence and Age}

Recovered in almost all sections, sometimes in considerable abundance. It is rare in the turriculatus Zone, and common in the spiralis to lundgreni/testis zones.

\section{Genus PARAPLECTOGRAPTUS Płíbyl, 1948}

Diagnosis

Ancora four-pronged; corona simple, of few meshes, somewhat rhomboid in profile, and square in cross-section. Rhabdosome walls (clathrium) sharply angular. Virgula central proximally, quickly moving to ventral side and becoming incorporated in, and part of, ventral wall. Horizontal lists arise alternately on left and right sides of virgula and join outer walls. Dorsal wall either of zig-zag pleural lists connected directly to outer walls, or with very short horizontal lists connecting pleural lists to outer walls. Reticulum may or may not be present, lists generally few in number and finer than clathrium, sometimes more common in proximal region and absent in distal portions, and/- or may be more common along median line of rhabdosome. Clathrial seams face in, those of the reticulum face out.

Remarks

Paraplectograptus, as visualized in this study, incorporates the type Paraplectograptus eiseli (pl. 3, fig. 4) and "Plectograptus praemacilentus" of Bouček and Münch (1952) (PI. 3, figs. 2,5). In its simpler, more orderly morph this genus is superficially similar to Plectograptus (s.s.), but differs strikingly in possessing a virgula which is part of the ventral wall. The morphology of Paraplectograptus ranges from one with only a clathrium, to one with a moderately complex but delicate reticulum over the clathrium. The clathrial structures of species recognized herein are essentially identical.

Boucek and Münch (1952), in their discussion of Plectograp tus praemacilentus imply that the virgula of the Czech specimens is, like the typical Plectograptus, free throughout its length. However, an examination of their illustrations shows the virgula to be suspiciously straight throughout, an observation suggesting that the virgula in their material is probably attached. This is further suggested by an examination of flattened material from the Arctic identified as the same species by Lenz (1978). These flattened but well preserved specimens are clearly the same species as the uncompressed material studied herein, yet the attachment of the virgula to the ventral wall is recognizable only with difficulty, and then only after comparison with the uncompressed rhabdosomes. We suggest therefore that the virgula of the type $P$. macilentus of Czechoslovakia is attached.

Three species, $P$. eiseli, $P$. praemacilentus and $P$. sp. A are recognized in this study. $P$. eiseli has few reticular lists or none, is about $0.9 \mathrm{~mm}$ in width, and a thecal spacing of $6-7$ in $5 \mathrm{~mm}$, (slightly higher than that stated by Boucek and Münch (1952)). P. praemacilentus and $P$. sp. A (pl. 3, fig. 7) are characterized by the possession of a reticulum, that of the latter species being finer, denser and more disorderly over the entire surface, and/or more dense in the medial region. In some cases, the meshwork still retains a crude overall zig-zag pattern. The rhabdosomes of both are generally parallel-sided, up to $1.4 \mathrm{~mm}$ in width, and thecae number $5-7.5$ in $5 \mathrm{~mm}$.

Eisenack (1951) illustrated "Retiolites tenuis", a species subsequently described as "Gothograptus tenuis" by Obut and Sobolevskaya (1965). By comparison with early growth stages of our material (pl. 3, fig. 9), we feel that Eisenack's species is nothing more than a juvenile stage of $P$. praemacilentus.

\section{Occurrence and Age}

Very common in most sections; $P$. praemacilentus ranges in age from the turriculatus Zone (rare) to the nassa Zone; $P$. $\mathrm{sp}$. A ranges from the spiralis Zone to about the rigidus Zone (lower Wenlock). Both species are most abundant in upper Llandovery strata. P. eiseli is less common and ranges from the spiralis Zone to about "mid" Wenlock.

Genus GOTHOGRAPTUS Frech, 1897

Diagnosis (based primarily on $G$. eisenacki Obut and Sobolevskaya, 1965)

Corona rounded, width nearly equal to maximum width of rhabdosome which is attained at the level of the first theca, composed of a few irregular clathrial lists. Coronal meshwork made finer through addition of reticular lists, but maintains two large, adjacent basal-lateral pores. Rhabdosome of most specimens narrow rapidly distally and thecae generally number 3-4 per side. Clathrial pattern complex and irregular; reticulum well developed, relatively fine, list widths becoming coarser with maturity. Thecae long, outer margins undulose (pl. 2, figs. 13,14), overall rather similar in profile to those of Pseudoglyptograptus, apertures generally horizontal. Meshwork of tubular appendix finer than that of more proximal regions. Virgula moves to ventral side early in development, but becomes at- 
tached to, and incorporated in, ventral wall about two-thirds along length of typical rhabdosome, then joined by alternating left and right bars for remainder of length; extends beyond rhabdosome. Seams of clathrium face in, and those of reticulum face out.

\section{Remarks}

The species recognized in this study, $G$. eisenacki, characteristically possesses only $3-4$ thecae per side, but may range from 2 to 5 or rarely more; typically narrows rapidly distally and, most uniquely, possesses thecae more like those of Pseudoglyptograptus than Climacograptus. It differs from the type additionally in being consistently smaller, in possessing a relatively coarser reticulum (particularly that of the thecal margins), and in that the virgula is free for a relatively much greater part of its length. No hint of such thecal hoods as illustrated for $G$. nassa by Wiman (1896) is present.

\section{Occurrence and Age}

Found only at Laura Lakes area and Rookery Creek in the latest Wenlock nassa beds.

\section{Genus HOLORETIOLITES Eisenack, 1951}

Remarks

The genus is represented by only two partial specimens, probably assignable to $H$. simplex (Eisenack) (1935) from Lower Ludlow strata. The thecae are climacograptid and appear to number 2 per side, the clathrium is simple and more or less zigzag, and the distal appendix is not developed. The fine structure is pustulose.

\section{Occurrence and Age}

Found only at Laura Lakes area in Lower Ludlow strata.

\section{Stratigraphic Distribution of Retiolitids}

The present study extends or modifies the stratigraphic ranges of the taxa Retiolites, Stomatograptus, Paraplectograptus and Plectograptus (Sokolovograptus). In most cases, the ranges of the genera are considerably extended beyond that shown in the literature, particularly that of Rickards, et al. (1977).

A composite of the zonal schemes of Thorsteinsson (1958) and Lenz (1978) from the Arctic Islands, and Lenz (1982) from the northern Cordillera, is used as a standard against which to display the stratigraphic ranges of the taxa recognized in this study (Table 1). It must be emphasized that the study is a preliminary one, and that subsequent recovery of additional material and taxonomic revision could alter the ranges somewhat.

In their section on the evolution of the retiolitids, Rickards, et al. (1977) relied heavily on their assessment of the stratigraphic ranges of the taxa. In view of the much extended ranges of most of the genera and species recovered in this

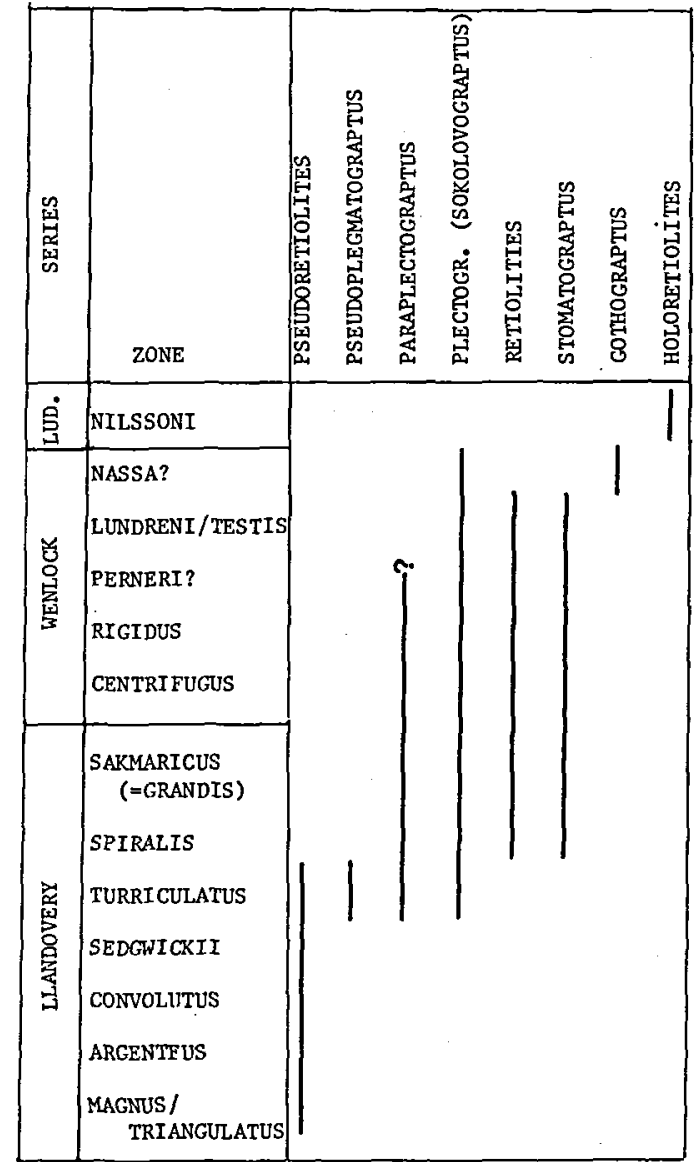

Table 1. Biostratigraphic ranges of Arctic Islands retiolitids. Zonal scheme extracted from Thorsteinsson, 1958; Lenz 1978, 1982.

study, it is clear that the evolutionary history must be completely reevaluated. Furthermore, much more attention must be directed to the development of the clathrium and reticulum in order to understand the phylogenetic relationships.

Acknowledgements. Hermann Jaeger very kindly sent photographs of isolated specimens of Plectograptus macilentus, and Peter Crowther offered a number of written comments on retiolitids in general. $R$. Thorsteinsson directed Melchin to the Cape Manning section, and A. D. McCracken collected some material from Marshall Peninsula and Rookery Creek. Financial support for field and laboratory studies was through a Natural Sciences and Engineering Research Council operating grant to Lenz; transportation costs to the field were supplied to Melchin by the Northern Research Group of the University of Western Ontario; and air support in the field was through the Polar Continental Shelf Project of the Department of Energy, Mines and Resources. 


\section{Dansk sammendrag}

De retiolitide graptolitsłægter Pseudoretiolites, Pseudoplegmatograptus, Paraplectograptus, Plectograptus, Retiolites, Stomatograptus, Gothograptus og Holoretiolites beskrives fra den arktisk canadiske Cape Phillips Formation. Den biostratigrafiske spandvidde er fra mellem llandovery (magnus/triangulatus zonen) til nedre ludlow (nilssoni zonen).

På basis af overflade ornamentikken bliver Retiolitinae og Plectograptinae emenderede. Paraplectograptus emenderes til også at inkludere former med et retikulum.

\section{References}

Andres, D. 1977: Graptolithen aus ordovizischen Geshieben und die frühe Stammesgeschichte der Graptolithen. Paläont. Z. 51, 52-93.

Bates, D. E. B. and Kirk, N. H. 1978: Contrasting modes of construction of retiolite-type rhabdosomes. Acta pal. Polonica $23,427-448$.

Bjerreskov, M. 1975: Llandoverian and Wenlockian graptolites from Bornholm. Fossils and Strata 8, 0-94.

Bouček, B. and Münch, A. 1944: Die Retioliten des mitteleuropäischen Llandovery und unteren. Wenlock. Mitt. Tschech. Akad. Wiss. 53 (41), 1-54.

Bouček, B. and Münch, A. 1952: The central European Retiolites of the Upper Wenlock and Ludlow. Sbomik Ustred. ustav. geolog., odd. pal. 19, 0-151.

Bulman, O. M. B. 1938: Graptolithina. In Schindewolf, O. H. (ed.). Handbuch der Paläozoologie 2D, 0-92.

Bulman, O. M. B. 1970: Graptolithina with sections on Enteropneusta and Pterobranchia. In Teichert, C. (ed.). Treatise on Invertebrate Paleontology, Pt. 5. Geol. Soc. Am. and University Kansas, xxxii +163 p.

Chen, X. 1983: Silurian graptolites from southern Shaanxi and northern Sichuan with special reference to classification of Monograptidae. Pal. Sinica, Whole No. 166, n.s. B (20), 1-102.

Crowther, P. R. 1981: The fine structure of the graptolite periderm. Spec. Pap. Pal., Pal. Ass. 26, 0-119.

Crowther, P. R. and Rickards, R. B. 1977: Cortical bandages and the graptolite zooid. Geologica Palaeont. 11, 9-46.

Eisenack, A. 1931: Retiolites Mancki. Ein neuer Retiolites aus dem norddeutschen Geschiebe. XXIII. Bericht Naturwiss. Gesell. Chemnitz, 35-42.

Eisenack, A. 1935: Neue Graptolithen aus Geschieben baltischen Silurs. Palaont. Z. 17, 73-90.

Eisenack, A. 1951: Retioliten aus dem Graptolithengestein. Paläontogr., Bd. C, Abt. A, 129-163.

Eisenack, A. 1966: Einige Bemerkungen über Retioliten und Graptoliten. N. Jb. Geol. Paläont. Mh. 10, 577-589.

Elles, G. L. and Wood, E. M. R. 1908: A Monograph of British Graptolites, pt. 7. Palaeontogr. Soc., cxxi-cxlviii, 273-358.
Huo, Shih-cheng 1957: Some Silurian graptolites of the Family Retiolitidae from Liangshan, Hanchung. Acta Pal. Sinica, $5(4), 513-522$.

Holm, G. 1890: Gotlands Graptoliter. Bihang Till K. Svenska Vet-Akad. Handl. 16 (4), 1-29.

Hutt, J. E. 1974: The Llandovery graptolites of the Lake District, pt. 1. Palaeontogr. Soc. Mon.; 1-56.

Jackson, D. E., Lenz, A. C. and Pedder, A. E. H. 1978: Late Silurian and Early Devonian graptolite, brachiopod and coral faunas from northwestern and arctic Canada. Geol. Assoc. Can., Sp. Pap. 17, 1-159.

Kühne, W. G. 1953: The prosicula of Retiolites geinitzianus Barr. Geol. Mag 90, 444.

Lenz, A. C. 1978: Llandoverian and Wenlockian Cyrtograptus, and some other Wenlockian graptolites from northern and arctic Canada. Geobios 11 (5) 623-653.

Lenz, A. C. 1982: Llandoverian graptolites of the northern Canadian Cordillera: Petalograptus, Cephalograptus, Rhaphidograptus, Dimorphograptus, Retiolitidae, and Monograptidae. Royal Ont. Mus., Life Sci. Contrib. 130, 1-154.

Münch, A. 1952: Die graptolithen aus dem anstehenden Gotlandium Deutschlands und der Tschechoslowakei. Geolog. ica 7, 1-157.

Obut, A. M., Sobolevskaya, R. F. (and Bondarev, V. I.) 1965: Graptolity Silura Taimyra. Akad. Nauk SSSR, Sibirskoe otdel, Inst. Geol. Geofiz, 1-120.

Obut, A. M. and Zasalvskaya, N. 1976: New data on the early stages of Retiolitidae development, 119-126. In Kaljo, D. and Koren, T. (eds.) Graptolites and Stratigraphy. Acad. Sci. Estonian SSR, Inst. Geol.

Perner, J. 1899: Studie o Českých Graptolitech, cst. 3. Monografie graptolitu svrchniho Siluru. Česká Akad. Cis. Fran. tiška Josefa, Tr. 2, 1-39.

Rickards, R. B. 1967: The Wenlock and Ludlow succession in the Howgill Fells (north-west Yorkshire and Westmorland). Quart. J. Geol. Soc. London 123, 215-251.

Rickards, R. B., Hutt, J. E. and Berry, W. B. N. 1977: Evolution of Silurian and Devonian graptoloids. Bull. Brit. Mus. (Nat. Hist.), Geol. 28, 1-120.

Schauer, M. 1971: Biostratigraphie und Taxionomie der Graptoliten des tieferen Silurs unter besonderer Berichtsichtigung der tektonischen Deformation. Freiburg. Forschungshefte C273, 1-185.

Thorsteinsson, R. 1958: Cornwallis and Little Cornwallis islands, District of Franklin, Northwest Territories. Geol. Surv. Can. Mem. 294, 1-134.

Thorsteinsson, R. and Kerr, J. W. 1968: Cornwallis Island and adjacent smaller islands, Canadian Arctic Archipelago. Geol. Surv. Can. Pap. 67-64, 1-16.

Törnquist, S. L. 1890: Undersokningar ofver Siljansområdets Graptoliter. Lunds Univ. Arskrift 26, pt. 1, 1-33.

Tullberg, S. A. 1883: Skånes Graptoliter. II. Graptolitfauna i Cardiolaskiffern och Cyrtograptusskiffrarne. Sverig. Geol. Unders. C (55), 1-43.

Wiman, C. 1896: Über die Graptoliten. Bull. Geol. Inst. Univ. Uppsala 2, 239-316. 